\title{
"Play, Score, Engage": Finding Ways for Boys to Make the Grade!
}

\author{
Carol-Ann Lane \\ Western University, Canada
}

\begin{abstract}
Media-generated headlines such as this, promote enthusiasm about video games as an alternative classroom strategy but this is frequently underscored in literacy and technology discourses as "wary" to address boys' literacy underachievement. These discourses help to frame educators' decisions that most video games' content can have a negative impact on behavior, may promote expressions of "toxic" masculinity [8] and therefore "influence" negative identity constructions [35] among players, particularly boys. Such discourses, have designated boys, as having difficulty "filtering" [24] videogame content in order to discover "good" learning experiences [16]. Furthermore, these existing assumptions, about how boys behave or respond to videogame play, are singularly labelled as a "hegemonic" [8] form of masculinity. In fact, by ignoring how boys can perform their masculinity in multiple ways and how they respond to video game multiliteracy opportunities, these discourses can contribute to the ways in which boys are homogenized. In addition, such discourses contribute in ways that prevent video gaming to be considered as an alternative classroom strategy to address boys' literacy underachievement, partly due to risks and concerns, spawned by the media, that boys would have difficulty in developing awareness about gender but also multiliteracy skills.
\end{abstract}

\section{Introduction}

\section{"Advocates are enthusiastic about the promise of video games in schools, but some educators are wary" \\ (Hopcock, J., A journalist for ABC news, June 13, 2008)}

Media-generated headlines such as this, promote enthusiasm about video games as an alternative classroom strategy, but this is frequently underscored in literacy and technology discourses as "wary" to address boys' literacy underachievement. These discourses help to frame educators' decisions that most video games' content can have a negative impact on behavior, may promote expressions of "toxic" masculinity [8] and therefore "influence" negative identity constructions [35] among players, particularly boys. Such discourses, have designated boys, as having difficulty "filtering" [24] videogame content in order to discover "good" learning experiences [16]. Furthermore, these existing assumptions, about how boys behave or respond to videogame play, are singularly labelled as a "hegemonic" [8] form of masculinity. In fact, by ignoring how boys can perform their masculinity in multiple ways, and how they respond to video game multiliteracy opportunities, these discourses can contribute to the ways in which boys are homogenized. In addition, such discourses contribute in ways that prevent video gaming to be considered as an alternative classroom strategy to address boys' literacy underachievement, partly due to risks and concerns, spawned by the media, that boys would have difficulty in developing awareness about gender but also multiliteracy skills.

Mario Bros. [26], Game of Thrones [40] and more than 40 years ago, Adventure [9], a text story video game, was released. Video games, such as these, could potentially address boys' underachievement in school and support recent recommendations by the Ontario Ministry of Education (MOE) to "harness" boys' interests in non-traditional literacy sources [4]. Although it is difficult to determine whether recommendations put forth by MOE are based on empirical investigations. For this reason, I wanted to investigate these recommendations further, to determine if boys' outside gaming practices would improve their literacy underachievement and, in doing so, recommend alternative class strategies such as video games. Therefore, recently, I conducted my ethnographic research study employing 'deep hanging' out [7] with four adolescent boys over a five month period. My study aimed to hear these boys' voices, as much as possible within their own social context, to better understand how they could develop multiliteracy skills as they engaged in video gaming. For this study, I examined ways that boys' out of school video gaming practices could contribute to improving their multiliteracy skills. To help me better understand my research problem, supported by theoretically informed research, my 
goal was to critically consider the nature of boys' out of school video gaming practices by empirically investigating to what extent these practices could positively affect their literacy achievement and gender construction in school. Ethnographically, I attempted to hear these boys' voices as they have been significantly lacking from the literature. Furthermore, the research questions had been prepared with the aim to situate these boys' voices

1) To what extent multiliteracies [25] practiced by boys through computerized video game technologies and surrounding networks manifest themselves in gender equality in secondary schools?

2) What differences can be seen in the types of video games that boys prefer to use outside of school?

3) Do these games differ among boys?

4) What levels of literacy content and stereotypical binary biases are embedded within the games chosen by the boys?

5) To what extent do boys engage in literacy activity and use surrounding networks during video game play?

6) In what ways do video game usage and surrounding networks act as contributing factors to students' literacy skills and subjectivity?

7) To what extent do boys present their masculinities or contradictory masculinities in nuanced ways as they play and compete with friends and other gamers in their video gaming practices outside of school?

Ongoing scholarly concerns exist about boys who play video games may potentially reinscribe negative social behaviors (e.g. Violent, misogynistic, dominating). However, counter to this, a study conducted in the US by Pew Research Institute [32], found teens' gaming experiences explored social concerns (more than 50\% reported thinking about moral and ethical issues while video gaming), relationship building and connection to civic duties or community life. My study draws on similar empirical evidence and my own research findings indicating significant ways boys resisted toxic behaviors in their engagement with video games.

The extensive amounts of data which emerged from my study was both rich and insightful. Much more detail could have been explored and discussed in this article based on the preliminary findings, which emerged from my fieldwork; however, I will only explore and discuss the research outcrop relating to the video gaming practices exhibited by one of the adolescent male participants. The study had been specifically aimed at understanding the ways in which boys' outside video game practices could contribute in improving their multiliteracy skills. There was no differentiation made for race and status, but my purposeful selection was based on adolescent males who had some interest or experience playing video games outside of school. Also, although gender was not a direct factor in my selection of these boys, I am informed by the theory of multiple masculinities [8] so it is important to establish that identity is "fluid" [6] and that boys maintains a "sense of their masculine identities" [23]. The reason I have highlighted identity is it became a factor in the preliminary data which emerged as it related specifically to indigenous culture. Again, I want to reiterate that this participant did not self-identify as First Nations; however, from the first moment he engaged with his video gaming interests and discussions with me in this study there were overwhelming signs of how he identified with First Nations' heritage. As an example, he expressed a desire to have Ojibway language integrated in all schools and he also regularly played a video game called "Never Alone" [10] which related to First Nations as it embedded storytelling features including videos given by the elders.

Given these strong indicators for First Nations heritage this has become important for me to pursue this research outcrop. The aim of my study is to investigate how boys' out of school video gaming practices can improve their literacy underachievement. In fact, both Canadian and International literacy agencies for student assessment have consistently reported boys have underachieved on literacy tests. I interpret these findings as an ongoing concern over boys' literacy and the growing need to explore alternative solutions which may alleviate further perpetuation of this issue. In a recent report by the Ontario Education Quality and Accountability Office (EQAO), Brochu, Deussing, Houme, and Chuy [4] identified "over the past 5 years fully participating females (students who actually wrote the test) successfully achieved the literacy test on average at $87.4 \%$, as compared to fully participating males with a successful achievement level of 80.2\%" (pp.67-68). In addition, a Statistics Canada study on gender inequality in Ontario by Brochu, Gluszynski, and Knighton, [5] reported that the Programme for International Student Assessment (PISA) in 2011 [34], showed "the average score for 15 year old students for combined reading indicated female students outperformed males by 37 points" (pp.7475). In fact, according to Statistics Canada, a 2008 study of Literacy skills of off-reserve First Nations and Metis students aged 16 and over indicated " $72 \%$ of First Nations in urban Manitoba and 70\% in urban Saskatchewan scored below Level 3 on the prose proficiency scale" [38]. This report acknowledged the growing crisis for underachievement among Aboriginal peoples. Compared to this, Indigenous 
youth literacy indicators are rarely reported in International literacy achievement reports such as the Organisation for Economic Co-operation and Development (OECD). OECD produces international evaluation reports on the quality and efficiency of school systems for government and policy makers. It conducted the 2012 Programme for International Student Assessment (PISA) [34] study, which raised concerns surrounding the boys' literacy gap. In fact PISA's [28] study in 2012 highlighted the gender gap favoring girls has increased over the past decade in more than 10 countries. The report suggested "this gender gap is particularly large in some high-performing countries, where almost all underperformance in reading is seen only among boys...policy makers need to promote boys' engagement with and commitment to reading" (p. 9).

In order to situate my inquiry, I explored additional Ontario Ministry of Education (MOE) reports to help me understand where literacy gaps existed and how these were associated with Aboriginal boys. Recent research addressed this in a report on the Education of Aboriginal students which indicated

Only $45 \%$ of the self-identified Aboriginal Grade 10 students were on track to graduate from high school, compared to $74 \%$ for all students in the Grade 10 population. This brings into question the Ministry's ability to meet its goal of significantly closing the achievement gap between Aboriginal and non-Aboriginal students by 2016. [29], (p. 131).

The MOE has attempted to respond to Aboriginal literacy underachievement by offering alternative schools for Aboriginal students. In fact, one Ontario school board boasts an Aboriginal education centre. Within this centre traditional curriculum is taught with the focus of First Nations' culture and language (Anishinabe cultural traditions for Kindergarten). This First Nations' school has been in operation since 1977 and focuses on grades 1 to 8 . This alternative school promotes "Native values, spirituality, culture and Ojibwe language throughout the school curriculum" [41]. Currently, this alternative school represents a very low enrollment of only 60 students. First Nations' schools, similar to this one, embrace Indigenous culture within the curriculum reflecting tradition based on language, music, dance, art and storytelling. However, the enrollment in these schools represents less than 1 percent of the Ontario Aboriginal student population. In fact, many Aboriginal students are enrolled in the non-alternative or regular provincially funded schools. It is the curriculum delivery in these schools I want to explore further in bridging the gap between Aboriginal students and literacy achievement.
This inquiry will attempt to consider the nature of Aboriginal boys' out-of-school video gaming by exploring to what extent these practices can be blended with literacy practices and preservation of Indigenous identity. It is suggested by a guide published by the MOE in 2004, Me Read? No Way! A practical guide to improving boys' literacy skills that boys will read books if they can find a reflection of themselves in the books [31], (Barrs, 1999, p. 3). If video games are designed with Indigenous cultural connections, using traditional elements of characters and storytelling, it may be possible to motivate Aboriginal boys to explore their video gaming practices to gain potential literacy skills while simultaneously preserving their cultural identity. In fact, many video games have been designed with a storyline. Sims City [11], Mario Bros. [26], Guitar Hero [18], Game of Thrones (Hunger games) [40] and Adventure [9] a text story video game was released more than 40 years ago. According to Hommel [20], a Pew Research study [32] indicated video games have been growing in popularity among adolescent boys and girls. Video game sophistication has also improved from text only to highly simulated $3-\mathrm{D}$ and new generation virtual gaming. Of course we can't discuss video games without considering some scholars - [1], [3], [14] - who raise major concerns about boys potentially acting out violently and exhibiting stereotypical behaviors when they frequently play video games. Yet, studies conducted recently provide quite a different perspective. In 2008, a US national study conducted by the Pew Research Institute found teens' gaming experiences to explore social concerns (more than 50\% reported thinking about moral and ethical issues while video gaming), relationship building and connection to civic duties or community life (more than $40 \%$ think about civic decisions). "The stereotype that gaming is a solitary, violent, anti-social activity just doesn't hold up. The average teen plays all different kinds of games and generally plays them with friends and family, both online and offline" [32].

As an elementary and high school teacher, my aim is to provide a safe, inclusive classroom, so I was still concerned about boys playing video games over an extended period of time (at home and maybe in the classroom). To ease some of my concerns I reviewed a meta-analysis by Sherry [36] who investigated playing video games (even violent ones) may trigger unwanted negative hegemonic behaviors. Sherry [36] found "longer player times result in less aggression” (p. 427). Similarly, Ferguson \& Kilburn [12] found that video game play had little or no effect on aggressive behavior. As a teacher of English, I wanted to consider how Aboriginal boys' video gaming practices may have the potential to transfer to literacy skills in school. But more importantly, how a video game can connect an experience, culture and self-reflection of 
a boy's cultural identity. One compelling reason for me is to promote and preserve the indigenous culture and traditions while intersecting boys' literacy.

\section{Literature Review}

What we can glean from the most recent MOE guides for boys' literacy is a strategy, suggesting to harness boys' attraction to computers in order to motivate them towards improved literacy practices. "Boys are reading all the time without picking up a book" [30] ( p. 53). Whether this relates to Indigenous boys will be the goal of this study to explore. Furthermore a recent 2013 study by EQAO recommended ways to increase boys' literacy development by expanding into print and digital formats.

Some game designers have begun to explore digitizing traditional stories and incorporating language, art or other Indigenous themes exposing minority cultures. This growing trend to blend Indigenous heritage, arts, and language is seen in one video game called "Never Alone (Kisima Ingitchuna)" [10]. It captures an array of images, languages and a story line which was developed in partnership with members of the First Nations' communities. The developers chose to work with community elders who represented Indigenous culture, identity and tradition. The elders enriched the video game storyline with traditional Indigenous oral folklore, art, symbols and meanings of inner spirit connected with nature. This type of game embodies narrative and artistic qualities which bridge technology and Indigenous culture.

What is absent from the literature and curriculum is exploring ways to preserve Aboriginal cultural identity and to explore a common space to continually maintain Aboriginal boys' voices. My research aim is to use alternative literacy sources such as video gaming as a key to better understand how Aboriginal boys explore their identity and literacy practices. In my view, there is a lack of concentration in this area and games has long been noted to have embedded narrative components. Shortcomings in the literature make evident the need to explore this area. Many articles have been written to outline diverse technological strategies to improve academic literacy achievement for Aboriginal students. These focused primarily on lack of resources such as computers and internet access on reserves, social justice and critical awareness of drug addiction and alcohol rather than integrating and preserving Indigenous culture in publicly funded offreservation schools as a means to create an improved literacy experience for Aboriginal boys. PirbhaiIllich and Austin conducted a study in 2009 [33] using an intervention method involving multimodal media production (MMP). The study mirrors alternative schools in place in an Ontario school board. These schools also incorporate authentic cultural pedagogy such as oral, storytelling, dance and music; however, they have indicated ongoing low enrollment so the overall positive effect may be lower. What is lacking is finding ways to modify curriculum taught in mainstream publicly funded schools representing higher enrollment of Indigenous students. Pirbhai-Illich and Austin's [33] study explored cultural relevant content, but focused on social justice issues such as drugs and alcohol rather than messages of preserving Aboriginal identity. However, by taking this one step further and interrogating the intersection of video gaming and Indigenous culture, I will explore in which ways boys construct their identity [27] and accept or reject their potential in literacy practices in a seemingly unregulated environment (outside of school or after school). If Aboriginal boys make connections to their Indigenous identity this could be bridged with their video gaming interests and potential literacy practices.

In fact, recent results suggest that boys' performance is increased with the use of computer assisted reading [4]. Furthermore, Akkerman et al. [2], Gros [17], and Huizenga et al. [21] recognize the lack of research documenting links between video gaming skills and academic performances. Furthermore, most video games contain narrative elements resembling books (characters, plot, etc.) offering boys opportunities to engage in discussions collaboratively with other gamers online - [15], [16], [39]. Both narrative and collaborative elements of video games, if applied by boys, can lead to the potential richness of literacy practices [22]. With this gap in literature, more attention is needed to understand the effects of video games (violent and nonviolent) to explore both the awareness of literacy potential and preserving Indigenous culture. A historical review of media literacy by Hoechsmann, and Poyntz, [19] revealed an increased reliance on digital media, digital literacy and communication technology over traditional print especially for youth. Their arguments position the changing pace of multiliteracies and media education but lack specific connection to Aboriginal boys' underachievement in literacy.

\section{Theoretical Framework}

The theoretical framework informing my ethnographic research is poststructuralist feminism [43] and preserving the identity through decolonization of Indigenous culture [42]. I will also draw on critical literacy theory for video gaming technology - [16], [37]. The heart of my question is to explore ways in which Aboriginal boys' interest in video games can impact their literacy practices in school. Aboriginal boys' may become inhibited in their perspectives towards literacy and schooling as 
they may resonate with oppressive experiences learned from their elders. By combining a feminist and Indigenous lens approach, I can discover ways to elevate voices which have been disrupted by oppression throughout history. Smith's [42] ethnographic research approach informs my work through vocalizing, visualizing and understanding decolonization issues through the experiences of the Maori (Indigenous peoples in New Zealand). This helps to situate my research as I explore ways that Aboriginal boys play video games to construct meaning in literacy and identity.

\section{Methodology}

Guided by my constructivist framework, I will use a mixed convergent, qualitative ethnographic approach [13] and Indigenous methodology [42] to explore the intersection of boys' video gaming literacy and preserving Aboriginal cultural identity. This method will involve 'deep hanging out' with 14-15 year old Aboriginal adolescent boys so that I can explore how they interact with the surrounding gaming community in their out-of-school video gaming practices. For this mixed convergent approach I would use this as an intervention (such as a video game) in a grade 10 classroom with approximately 30 adolescent boys, self-identified as Aboriginal, from a South Western Ontario school one ranked with high ethnicity status and low social economic status (SES)). The intervention, which represents the quantitative phase of my research, will involve the use of the video game technology by one grade 10 classroom of Aboriginal boys (this would involve the students' interactive use of a game such as "Never Alone" [10] for an entire term to determine a correlation to improved literacy practices determined by the scores performed on the Ontario Secondary School Literacy test (OSSLT) for grade 10; this will inform the quantitative element of my research. During my research intervention study, a parallel, non-controlled group would be used represented by a second classroom of adolescent boys of Aboriginal identity (approximately 30 students) who will not receive any exposure to the "Never Alone" [10] game or use in the classroom. For the qualitative phase of my mixed methods research I will randomly select 15 adolescent boys (those who had exposure and no exposure to the "Never Alone" [10] game), from the population results (both classrooms of 60 adolescent boys), to participate in a qualitative case study approach. This phase may have ethnographic elements as I will explore the external interests and experiences of boys using video game technology. During this in-depth research I will observe the students at home and in school, over a period of time (approx. 6-8 weeks). This approach will enable me to explore a deeper contextual meaning through boys' voices, interests and literacy practices both inside and outside of school. During post-observation I will also conduct semi-structured interviews with the boys to understand their stories and experiences about literacy and their identity when they play video games alone, with their peers or with online gamers.

\section{Conclusion}

The intent of the study is to explore preserving Aboriginal cultural identity that could be embedded in video games and how Aboriginal adolescent high school boys could respond to these games in and outside of school which may contribute to their improved literacy practices. Given my recent preliminary findings indicating significant tendencies towards preserving Aboriginal identity in the ways that one of these boys illustrated through his desire to specifically play with the game "Never Alone" [10] and resisting to play other games, along with his desire to discuss in depth with others about the narrative qualities of this game, part of my future planned research will be to examine the ways boys learn and interact with these types of video games to address their literacy underachievement. It is conceivable that this in-depth ethnographic research will guide educators and ministry administrators, through collaborative efforts with the Indigenous communities, to potentially reverse the gap for atrisk boys' in general and the burgeoning crisis for Aboriginal literacy underachievement. The research is anticipated to provide indications that Aboriginal boys' interest will be well served in improving literacy performance of video game play while also ensuring a continual renewal and re-emergence of their Aboriginal identity both in and out of school.

\section{References}

[1] Ajayi, L. (2011). A multiliteracies pedagogy: Exploring semiotic possibilities of a Disney video in a third grade diverse classroom. The Urban Review, 43 (3), 396-413. doi: 10.1007/s11256-010-0151-0

[2] Akkerman, S., Admiraal, W., \& Huizenga, J. (2009). Storification in history education: A mobile game in and about medieval Amsterdam. Computers \& Education, 52 (2), 449-459. doi: 10.1016/j.compedu.2008.09.014

[3] Apperley, T., \& Beavis, C. (2011). Literacy into action: Digital games as action and text in the English and literacy classroom. Pedagogies, 6 (2), 130. Retrieved from http://search.proquest.com. proxy1.lib.uwo.ca/docview/869913792?accountid=1 5115. (Access date: October 2012)

[4] Brochu, P., Deussing, M.A., Houme, K., \& Chuy, M. (2013). Measuring up: Canadian results of the 
OECD PISA study: The performance of Canada's youth in Mathematics, Reading, and Science: 2012 first results for Canadians aged 15. (Fifth Report). Toronto, Ont.: Council of Ministers of Education, Canada. Retrieved from http://www.cmec.ca/ 252/Programs-and-Initiatives/Assessment/ Programme-for-International-Student-Assessment\%28PISA\%29/PISA-2012/index.html.(Access date: January 2014)

[5] Brochu, P., Gluszynski, T., \& Knighton, T. (2010). Measuring up: Canadian results of the OECD PISA study: The performance of Canada's youth in reading, mathematics and science: 2009 first results for Canadians aged 15. (Research Report No. 4). Ottawa, Ont.: Human Resources and Social Development Canada, Statistics Canada. Retrieved from http://publications.gc.ca/collection_2010/ statcan/81-590-X/81-590-x2010001-eng.pdf (Access date: 12 October 2012)

[6] Butler, J. (1990). Gender trouble: Feminism and the Subversion of Identity. In L. J. Nicholson (Ed.), Feminism/PostModernism (pp. 1-170). New York: Routledge, Chapman and Hall, Inc.

[7] Clifford, J. (1997). Routes: Travel and Translation in the Late Twentieth Century. Cambridge: Harvard University Press.

[8] Connell, R. (1996). Teaching the boys: New research on masculinity, and gender strategies for schools. Teachers College Record, 98 (2), 206-235.

[9] Crowther, W., \& Woods, D. (1976). Colossal Cave Adventures. Retrieved from

http://rickadams.org/adventure/. (Access date: December 2013)

[10] E-Line Media \& Cook Inlet Tribal Council (2016). Never Alone (Kisima Ingitchuna). Retrieved from http://neveralonegame.com/. (Access date: August 2015)

[11] Electronic Arts, Inc. (2014). Sims City. Retrieved from http://www.simcity.com/. (Access date: January 2014)

[12] Ferguson, C. J., \& Kilburn, J. (2010). Much ado about nothing: The misestimation and overinterpretation of violent video game effects in eastern and western nations: Comment on Anderson et al. (2010). Psychological Bulletin, 136 (2), 174178. doi:10.1037/a0018566

[13] Fetterman, D. M. (1998). Ethnography: Step by step. Thousand Oaks, Calif.: Sage Publications.
[14] Foster, A. N. (2009). Gaming their way: Learning in simulation strategy video games? (Ph.D., Michigan State University). ProQuest Dissertations and Theses, Retrieved from http://search.proquest. com.proxy1.lib.uwo.ca/docview/304946067?account $\mathrm{id}=15115$. (304946067). (Access date: January 2014)

[15] Gee, J. P. (2003). What video games have to teach us about learning and literacy (1st ed.). New York: Palgrave Macmillan.

[16] Gee, J. P. (2007). Good video games and good learning: Collected essays on video games, learning, and literacy. New York: P. Lang.

[17] Gros, B. (2007). Digital games in education: The design of games-based learning environments. Journal of Research on Technology in Education, 40 (1), 23-38. Retrieved from http://search.proquest. com.proxy1.lib.uwo.ca/docview/274710337?account $\mathrm{id}=15115$. (Access date: March 2013)

[18] Harmonix (2009). Guitar Hero. Red octane. Retrieved from https://www.guitarhero.com/ca/en/. (Access date: January 2014)

[19] Hoechsmann, Michael, and Poyntz, Stuart, R. (2012). Media Literacies: A critical introduction. Malden, MA; Chichester, UK. Wiley-Blackwell.

[20] Hommel, M. (2010). Video games and learning. School Library Monthly, 26 (10), 37-40. Retrieved from http://search.proquest.com.proxy1.

lib.uwo.ca/docview/347842388? accountid=15115. (Access date: January 2016)

[21] Huizenga, J., Admiraal, W., Akkerman, S., \& Dam, G. (2009). Mobile game-based learning in secondary education: Engagement, motivation and learning in a mobile city game. Journal of Computer Assisted Learning, 25 (4), 332-344. doi: $10.1111 / \mathrm{j} .1365-2729.2009 .00316 . x$

[22] Ke, F. (2008). A case study of computer gaming for math: Engaged learning from gameplay? Computers \& Education, 51 (4), 1609-1620. doi: 10.1016/j.compedu.2008.03.003

[23] Lingard, B., \& Douglas, P. (1999). Men engaging feminisms: Pro-feminism, backlashes and schooling. Buckingham, England; Philadelphia: Open University Press.

[24] NewKirk, T. (2002). Misreading masculinity: Boys, literacy, and popular culture. Heinemann, 361 Hanover Street, Portsmouth, NH 03801-3912 (19). Retrieved from http://search.proquest.com/ docview/62201481?accountid=15115._(Access date: April 2013) 
[25] New London Group. (2000). A pedagogy of multiliteracies: Designing social futures. In B. Cope \& M. Kalantzis. (Eds.), Multiliteracies: Literacy learning and the design of social futures. London; New York: Routledge.

[26] Nintendo of America, Inc. (2016). Mario Brothers. Retrieved from http://mario.nintendo.com/. (Access date: October 2015)

[27] Mac an Ghaill, M. (1994). The making of men: Masculinities, sexualities and schooling. Buckingham; Philadelphia: Open University Press.

[28] OECD. (2013). 2012 Results in Focus: What 15-year-olds know and what they can do with what they know: Key results from PISA 2012

http://www.oecd.org/pisa/keyfindings/pisa-2012results.htm._(Access date: January 2014)

[29] Office of the Auditor General of Ontario. (2012). Ministry of Education. 2012 Annual Report of the Office of the Auditor General of Ontario. Chapter 3, Section 3.05 Education of Aboriginal Students. http://www.auditor.on.ca/en/ reports_2012_en.htm._(Access date: January 2014)

[30] Ontario Ministry of Education. (2009). Me read? And How! Ontario Teacher's report on how to improve boys' literacy skills. Toronto: Ministry of Education. Queen's printer for Ontario. Retrieved from http://www.edu.gov.on.ca/eng/

curriculum/boysliteracy.html. (Access date: October 2013)

[31] Ontario Ministry of Education. (2004). Me read? No Way! A practical guide to improving boys' literacy skills. Toronto: Ministry of Education. Retrieved from http://www.edu.gov.on.ca/eng/ teachers/publications.html\#2004. (Access date: October 2013)

[32] Pew Research Institute (2008). Teens, Video games and Civics. US. Retrieved from (http://www.pewinternet.org/2008/09/16/major-newstudy-shatters-stereotypes-about-teens-and-videogames/). (Access date: January 2016)

[33] Pirbhai-Illich, Fatima, Nat Turner KC, \& Theresa Y. Austin. (2009). Using digital technologies to address Aboriginal adolescents' education. Multicultural Education \& Technology Journal 3, (2): 144-162,http://search.proquest.com/ docview/229079419? accountid=15115. (Access date: 23 August 2015)
[34] PISA (2012) Results in Focus: What 15-yearolds know and what they can do with what they know: Key results from PISA 2012. http://www.oecd.org/pisa/keyfindings/pisa-2012results.htm. (Access date: January 2014)

[35] Sanford, K., \& Madill, L. (2006). Resistance through video game play: It's a boy thing. Canadian Journal of Education, 29(1), 287-306,344-345. Retrieved from http://search.proquest.com/ docview/215378045 ?accountid=15115.

(Access date: January 2015)

[36] Sherry, J. (2001). The effects of violent video games on aggression. A meta-analysis. Human Communication Research, 27 (3), 409-431. doi:10.1093/hcr/27.3.409

[37] Squire, K. D. (2013). Video game-based learning: An emerging paradigm for instruction. Performance Improvement Quarterly, 26 (1), 101130. doi: 10.1002/piq.21139

[38] Statistics Canada. (2008). Study: Literacy skills of off-reserve First Nations and Metis in urban Manitoba and Saskatchewan. Retrieved from http://www.statcan.gc.ca/daily-quotidien/ 080107/dq080107a-eng.htm. (Access date: March 2016)

[39] Steinkuehler, C., Squire, K., \& Barab, S. A. (2012). Games, learning, and society: Learning and meaning in the digital age. Cambridge: Cambridge University Press.

[40] TellTale Games, Inc. (2016). Game of Thrones. Retrieved from https://www.telltalegames.com/ gameofthrones/. (Access date: January 2014)

[41] Toronto District School Board (2014). Kindergarten at First Nations School. Retrieved from http://www.tdsb.on.ca/Community/

AboriginalEducation/Schools.aspx..(Access date: March 2016)

[42] Tuhiwai Smith, L. (1999). Decolonizing methodologies: Research and indigenous peoples. London; New York: Zed Books.

[43] Weedon, C. (1997). Feminist practice \& poststructuralist theory (2nd ed.). Oxford, UK; Cambridge, Mass.: Blackwell Publishers. 